\title{
From the Bestiary: Political Section
}

\section{Kenneth Lash}

Dick Whitehouse might or might not have been born blind. He is definitely blind by the time we get to see him.

He is a young adult. He has a skinny, brush-haired dog named Fritz. They're separable by night (Fritz sleeps where he pleases), but not by day. Day means up and ready for Fritz, tramping about with Dick. Though he isn't conscious of it, Dick likes to tramp; in fact it's what he does naturally. For a blind fellow neighborhoods are both much the same (sidewalks and curbs) and very different (sounds and smells), but never different enough to be unique. It's advisable to have sight if it's uniqueness you're after, but without sight you gain a lot because there's no call to get sentimental over things. So for example Dick Whitehouse tramped from place to place to place, neighborhood to neighborhood, freely, at ease. As great travelers have said, you start by being a stranger everywhere, end by being a stranger nowhere. Or was it at home nowhere? No matter. With Fritz, Dick tramped.

Fritz was a biter. Except for Dick, he bit anything that he came near, that came near him, or that he bumped into. Dick didn't discourage this, after he found it served to enlarge his free space, give him more room. He made up a joke, which he told nobody: "I've got a biting-eye dog." Often the one bitten, or the one accompanying the one bitten, wanted to bash Dick for it, but saw that Dick was blind, and most of us can't go much beyond that "Take off your glasses!" business, though we're learning from movies and TV and I'm not sure the Dicks of tomorrow are going to be that safe. Even Dick Whitehouse, maybe forging through minority neighborhoods, began to feel himself not entirely safe from reprisal over Fritz's biting everybody, so he developed a smile. Or what he took to be a smile, after asking for a description of one. He found it tiring to his face muscles, but he did it, he used it. Probably a lot more than he had to, because he was never able to be certain when it was necessary. A lady who sold them hamburgers told Dick, after he started smiling, that he and Fritz were becoming look-alike. The statement meant nothing to Dick. What nobody told him, but he 
probably sensed, is that smiling was a good thing if you were going to be a professional stranger. No way to do without it, unless you're armed and ready. Counting Fritz, Dick now had it both ways.

But what, anymore, can you count on? Life is all change these days. One afternoon in May, Dick and Fritz tramped right off the streets and into a woods. Neither had ever done this before, never been in a woods, it just hadn't chanced. They were both taken aback. What sounds, what textures, what smells! For Fritz it was like stumbling into cinema verité, where as his jaw dropped open the images became suddenly three-dimensional, walked out of the screen and were suddenly there right in front of him, real. Biteable. Chaseable. Crunchable. Within seconds he was crashing off after a hare without even knowing what a hare was.

Dick, on the other hand, felt an overpowering, absolutely undeniable urge to sit down, straight down where he was. It's just as well he felt that way because he'd have been a dead duck in there without Fritz. Sitting down amid the smells, Dick was suddenly also amid the feels. He put his hands down to sit and there they were on the ground, and they were the hands of a blind man, so they began to move here and there, feel, weigh, assess, tramp around. They brought things back, and if the things felt OK and smelt OK Dick tasted them. If they tasted OK, he ate them. And so for the first time in his life Dick House tasted such items as violets, fescue, lichens, urinated-upon leaves, moss both plain and snail-silvered, fennel, fenugreek, plain dried ant, and jack-in-the-pulpit. Also a small piece of poison ivy, which fortunately he proved immune to, without knowing it. All this on top of a tunafish sandwich, which Dick had eaten for lunch because it was Friday, which meant nothing to him but did to the hamburger lady, who was a convert to Christian Science but brought up Roman. Fritz, who also had a tunafish sandwich for lunch, showed up with his jaws sopping wet with blood (which Dick couldn't know) and belching (which he could). "You too, eh?" said Dick, rising up and patting his stomach. They tramped off home for a sleep. And awoke, all unaware, to a different life. Or at least Dick was unaware.

Fritz was up and raring to go in the morning, but Dick, narcotized by nature, slept late. That may or may not have made any real difference, but it was lunch time when they set out for their tramp. They went straight to the hamburger lady, and Fritz, with fresh hare in his mind, instantly bit her. Then he tried to eat her. She escaped up a drainpipe and clung there, blood dripping down the pipe from her fat left leg. Fritz sat below, happily lapping it up.

Dick Whitehouse narrowly escaped jail. As the records show, it was only his blindness that saved him. On the other hand it was his own effort, his harrowing eloquence, that saved Fritz from cyanide. Dick pledged everything and saved Fritz his life, but cost him a muzzle. It certainly seemed a worthwhile bargain, but it wasn't.

Fritz hadn't been born to be muzzled. He sulked, and sulking as you know requires concentration on yourself. Dragged along unthought-of, Dick found himself wrapped around poles, led into puddles, crossing streets against lights, setting out on adventurous routes only to find himself suddenly back at the starting 
point. It was a mess, a crisis. Fortunately an accident solved it. A fortunate accident. Led diagonally across a crosswalk, Dick was hit by a Cadillac.

Driving the Cadillac was a lady. As it ought to be but often isn't any more, the lady was well-to-do and frightened, the daughter of a general. She put Dick up in a hospital, Fritz in a kennel, and visited both of them every day. Fritz, whose fault the whole thing was if there is finally such a thing as fault, liked the lady. Maybe only because he was so mad at Dick. Anyway, he ate out of her hand instead of eating the hand itself. Dick liked her too. It was his first experience with compassion, probably because it had to do with his bones instead of his eyes. When he mended, they married. She proposed, Dick considered and accepted.

A cozy household was set up, at no little expense. By consensual agreement among all three, the lady took over Fritz's work. Fritz no longer felt any loyalty to the job, and would have retired anyway, on top of which he found himself rewarded for his resignation; since he could be left at home, off the streets, his muzzle was removed. Fresh horsemeat was brought to him. He went to work ferociously to get fat.

Though Dick's lady was a good lead animal, better than Fritz in some ways, she was not Fritz. For one thing, tramping was not natural to her. Going places was her forte. Here to there and for this reason. So a first consequence of the new deal was that Dick found himself more literally led. And once or twice with a sharp little pain he recalled Fritz's indifference. By and large though it was satisfactory, secure, and interesting. Outings added up, made a kind of sense, like mathematics. Dick was good at mathematics, and began to think of it a lot. $\mathrm{He}$ took over his lady's accounts, and managed them in ways that were innovative without being daring. And yet daring soon entered their lives.

It was the lady's doing. Being a lead lady, not a lead dog, she had her own compulsions. Her first step was constantly to improve her performance, which she did so effectively that Dick was thunderstruck one afternoon when he came up out of an accounts problem that had absorbed him for long minutes to find that he was walking the streets, holding onto nothing-no leash, no arm. He stopped in his tracks. "Darling! Darling!" he called. "I'm right here, dear," she answered quietly, and told him it had been weeks since she'd had to touch him to lead him. Dick could hardly believe it, but it proved to be so. He could indeed follow her without touching her. It was the beginning of a new era.

Step two derived from the lady's compulsion to improve Dick's performance as absolutely as she had improved her own, and to transfer the improvement intact. This meant, in the final analysis, that she would have to find a way to subtract herself from the equation, and yet do so without disturbing the balance. It was a tricky problem. She consulted specialists who, after a series of studies, informed her that scientifically speaking the problem reduced itself to that of displacing person with presence. A technique needed to be developed whereby, in effect, she went with Dick without actually doing so. It was not quite clear to the good lady. "You mean like giving him one of my canes, for instance?" (The lady had developed a little rocking limp after the car accident.) The 
scientist smiled fondly at her. He asked her for money and said he'd get to work on the problem.

One day six months later Dick was out in the streets happily going from here to there and doing the accounts in his head, when he suddenly stopped rigidly still and cried, "Darling! Darling!" These little moments of panic still happened from time to time. They simply overtook him and were there, without warning. It was awful because it made him feel helpless. His blindness never had, and he'd never felt panic with Fritz around. He often thought of confessing to his lady this awful price he was paying for his improvement, but he couldn't finally get himself to do it, so he smiled hard, and went on. But it cost something. "Darling! Darling!" he cried.

"I'm right here, dear," she said.

But of course she wasn't. Her synthesized smell was there (in his suits). Her voice was there (in a button under the back of his collar). And her eyes were there (she had him on private closed-circuit TV). Since for some time she had weaned him from touching her while on their walks he did not now attempt to do so. As soon as she responded with her "I'm right here, dear," he calmed at once; the panic drained off without a gurgle.

It worked. The system worked. There are harder things to believe.

So Dick went on getting about on his own without knowing it. $\mathrm{He}$ went from here to there and back better and better, doing accounts in his head. The lady watched him on TV, patting Fritz gently on his fat shoulder.

When the trouble came, it wasn't anybody's fault, really. The fault of mathematics, maybe, with its fatal tendency to get narrow if left unattended for more than minutes at a time. A 15-year-old student has recently demonstrated to IBM how childishly vulnerable computer systems are.

This particular system was brought down by the hamburger lady. Still smarting from her bites, injured by her lawsuit loss against Dick, she bore her grudge helplessly as long as Fritz was about, or even the lady, though the advent of the lady suggested, if no ideas, at least the possibility of ideas. She was working on them, but it wasn't her forte. Dick alone, however, unaccompanied, was a different affair. Action, no ideas necessary. The minute she saw him walking alone her engine turned, caught. If she hadn't gone from 0 to 60 with such blinding acceleration, Dick's lady, watching at home on TV, would have warned him. As it was there was simply a streak of gray like interference, a small squawking sound, and suddenly, impossibly, a picture of Dick lying in the gutter, mugged.

Mugged good, the lady saw as the picture cleared. She stared and stared at him, lying there. All that effort. So much effort. Her deep sigh made Fritz yawn. Slowly, reluctantly, she reached out and switched to a public channel. The old familiar programs were on. This Is Your Life. Walter Cronkite. "Oh dear," she said. "Oh dear dear dear." 